\title{
ACKNOWLEDGMENTS
}

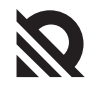

The editors of this book gratefully acknowledge the support of the Qatar Foundation and of Northwestern University in Qatar, who generously coprovided a subvention to Rutgers University Press in support of the publication of this volume. We are also thankful for the advice and leadership of Leslie Mitchner, Anne Hegeman, Lisa Boyajian, Katie Keeran, Suzanne Kellam, and Rutgers University Press. The guidance and wisdom of Patrice Petro was inspirational. Special thanks also to John Durham Peters for a sympathetic, critical, and effective reading of the manuscript in draft form, to Robert Burchfield for his careful copyediting, and to Betsy Lane of Lane Editorial, whose brilliant and timely assistance rescued this project from a series of late-mission wobbly orbits and took on the needed function of mission control. We also thank the contributors to this volume and are extraordinarily pleased to publish their work.

Lisa Parks would like to thank her wonderful colleagues in the Department of Film and Media Studies at the University of California at Santa Barbara for supporting her research interests in satellite technologies and media over the years. Her thinking about satellites also has been touched and informed by provocative exchanges with a number of researchers and artists, especially Jody Berland, Ursula Biemann, Charlotte Brunsdon, Amelie Hastie, James Hay, Francis Hunger, John Fiske, Joanna Griffin, Lisa Jevbratt, Geert Lovink, Patrick McCray, Angela Melitopoulos, David Morley, Marko Peljhan, Trevor Paglen, Nicole Starosielski, Jonathan Sterne, Ginette Verstraete, and Miha Vipotnik. Parks also has been inspired by the curiosities and questions of students in her Satellite Media courses at UC Santa Barbara and by artists who participated in the Zemos98 Conference in Seville, Spain and the Satellites/ Footprints/Borders Workshop at HMKV in Dortmund, Germany. Parks is grateful for the generous support of the Wissenschaftskolleg of Berlin, where she worked as a research fellow in 2006/2007 while this project was getting off the ground. She would also like to thank those who attended her talks at Central European University, Humboldt University, McGill University, University of Southern California, and University of Stockholm, where she received vital feedback on her chapters in this book. Finally, Parks expresses 
deepest gratitude to her coeditor and collaborator, James Schwoch, for his sweeping satellite intelligence, worldly vision, and stalwart friendship. Working on this book has opened new fields of inquiry for me and altered my course.

James Schwoch is thrilled to have had this opportunity to work with Lisa Parks. Lisa continues to expand my intellectual horizons about satellites and global security (as well as everything else germane to global media studies) and to help me in my never-ending pursuit of originality, rigor, and eloquence in my research, all the while a close friend. I look forward to our future collaborations. In addition to Lisa, I have benefited greatly in my career from the support of archivists, librarians, catalogers, and staffers at various institutions around the world. Archives of particular significance for this book include the National Archives and Records Administration (USA); the National Air and Space Museum; Smithsonian Institution (USA); Wisconsin Historical Society (USA); the Eisenhower, Kennedy, Johnson, and Reagan presidential libraries (all USA); and the British Telecomm (BT) Archives (UK). During the production of this book, I was intellectually boosted on various and general issues of satellites by lively audiences and interlocutors at the 2009 Cités De Telecom Doctoral Seminar held at Pleumeur-Bodou and sponsored by the Sorbonne, Maastricht University, and Orange (formerly France Telecom); a 2009 lecture at the Department of Film and Media Studies, University of California at Santa Barbara; a 2009 session at the Institute for Defense Analyses, Washington D.C.; a 2009 conference paper at the Aleksanteri Conference, University of Helsinki; a conference paper at the 2008 Society for the History of Technology Conference, Lisbon, and a 2008 Seminar Paper at ZiF (Institute of Advanced Study), Bielefeld. During this period of archival research and at these various venues, many individuals gave constructive advice, including Pascal Griset, Andreas Fickers, Richard John, Paul Ceruzzi, Michael Neufeld, W. Patrick McCray, Jason Gallo, and Alexander Geppert. Last but not least-a multitude of thanks to many students in the past twenty years who have generously allowed me to explore satellites and outer space as part of my teaching. Their enthusiasm, ranging from classroom comments to research papers, constitutes a wonderful affirmation of the value and relevance of satellites, global security, and outer space as lively topics for both the classroom and for research. 


\section{DOWN TO EARTH}


